DOI https://doi.org/10.30525/978-9934-26-065-0-16

Iryna Solyarska-Komarchuk, $\mathrm{PhD}$ in Philosophy, Associate Professor, Teacher of Physical and Mathematical Lyceum of Taras Shevchenko National University,

Kyiv, Ukraine

ORCID 0000-0002-3229-9153

\title{
WALKING MAN: FROM AESTHETICS TO ART PRACTICES
}

\begin{abstract}
The purpose of the paper is to identify the features of the development of contemporary art. An attempt is made to find out the reason for the emergence of art practices as a characteristic phenomenon of postmodernism through the concept of aesthetic experience, contemplation and to establish their essential difference from the traditional understanding of artistic creation. The author notes the dependence of the modification of art forms on the internal existential states of man.

The methodology of the study. The presented research has a complex interdisciplinary nature, thus, its implementation required methods and approaches, which provided a reflection of the multifaceted nature of the study of contemporary art. The system approach allowed to study the artistic processes of today as a result of internal transformations of man and society, which began in the twentieth century. The study combines art, philosophical, cultural and psychological approaches.

The scientific novelty of the publication is to establish the causes of the phenomenon of art practices in the second half of the twentieth century and the emergence of the need of the contemporary artist to find artistic and figurative solutions in the inner depths, "landscapes of the soul", signifying distrust of the world of objective truths. The concept of mythopoetics is introduced as a result of the artist's inner experience and the source of figurative thinking. The example of the Kyiv rearguard association reveals the peculiarities of contemporary Ukrainian art in the context of world artistic processes and emphasizes their preservation of the tradition of contemplative thinking about the world, which is also characteristic of the Ukrainian avant-garde.

Conclusions. One of the main problems of contemporary art is the need to distinguish between art practices that deliberately refuse to transmit aesthetic experience and the artistic creation itself, which is associated with the desire to reflect reality through metaphor and figurative-symbolic language. The crisis of traditional values caused by the consequences
\end{abstract}


of the Second World War leads to the artist's immersion in the world of subjective experiences and to mythopoetic thinking. Artists of the "Kyiv rearguard" try to comprehend existential problems in their work, using images of their own mythopoetics, continuing the tradition of contemplative reasoning

Keywords: art practices, artistic creation, aesthetic experience, contemplation, metaphor, mythopoetics, Kyiv rearguard.

Art is a universal form of reflection, expression, appreciation or knowledge of a phenomenon, not its own existence $[3,121]$. Therefore, in modern art history the problem of the parallel existence of such concepts and phenomena as "art practice" and "artistic creation" is particularly acute. Based on certain notions of postmodernism, such as irony, play on words, lack of metanarratives, etc., unpretentious forms of various "arts" have been penetrating the art world since the second half of the twentieth century. We should remind that art has the ability to express the spiritual, aesthetic, cultural and moral state of society. And it is in this plane that irreversible processes have taken place, which have changed both social and aesthetic orientations.

Russian scientist V. Bychkov notes: "At the same time, both the general philosophy of art and modern aesthetics have ceased to see in art the concentration, the quintessence of aesthetic experience. Nowadays, artists, art critics and aesthetics have completely forgotten about it. I see in this not just a temporary dizziness of modern "advanced" art society, which, in fact, has its own explanation, but a clear sign of spiritual and aesthetic decline, which is actually inherent in the modern post-cultural situation [1, 225-226]. He also remarks that "art at the metaphysical level is the only essential principle and criterion of authenticity of art and will remain so until humanity finally loses the ability to experience aesthetic experience and aesthetically perceive the world" [1, 225-226].

Thus, aesthetic experience can be considered the main criterion in recognizing artistic creation and art practices. In the first case, there is a desire to represent "semantic depths" through images that require the use of figurative and symbolic language. "Art practice is characterized by a conscious rejection of art, skill, aesthetic pleasure in favor of conceptualism, intellectual satisfaction. Performances, actions, objects, installations are focused not on the functions essential for art, but on the accompanying ones, both traditional - communicative, 
political, informational, cognitive, and innovative - procedural and interactive. They are mostly designed for provocation, shock. Their vector lies in blurring the boundaries between art and non-art" [1,228].

Aesthetic experience implies a dialogue between man and the world. It breaks the chasm of misunderstanding and alienation from the world around, overcomes the obsession with subjective experiences and creates an understanding of coexistence, cohabitation and belonging. In the artistic dimension, metaphor becomes the main means of transmitting these deep processes. "So the metaphor brings together objects, which belong to different classes. The main feature of the metaphor is its duality. The figurative metaphor performs a characterizing function: the signifying (figurative) metaphor performs the task of creating "invisible worlds" - the inner landscape of the artist with a kaleidoscope of hints, symbols, analogies, emotional impressions..." [5, 111]. The main mechanism of the metaphor is transference, the search for analogy and consonance.

Art practices, which the second half of the XX and the beginning of the XXI century abound in, have become an expression of distrust, tension of the author; they are designed for the moment in which the authors are. It is not a metaphor that is the main means of expression here, but the action of one's own body, or a concept that the vigilant spectator must consider, or irony, deformation, designed for shock. Almost all researchers of art (philosophers, culturologists, art critics, psychologists, etc.) note that the shift in the understanding of art occurred in the postwar period (second half of the twentieth century), after World War II. Nothing like this has happened in the history of art for millennia! Art has consciously abandoned its aesthetic principle, its essence - high artistic value. Correspondingly, to approach it you need a different optics, not aesthetic. We don't need a different aesthetics, the essence (i.e. the subject) of aesthetics as part of ethics and epistemology is always the same. We need another non-aesthetic optics. However, in this case, it will no longer be art, but something else", emotionally notes V. Bychkov [1, 227].

The catastrophe of humanity, i.e. the war, affected the rethinking of values. Aesthetic experience lost its dominance, its place was taken by an abyss of questions. People found themselves alone with their injuries, irreparable losses, loneliness, shame and despair. And abstraction is often the only language in which we can speak of this catastrophe. It was during this period that Alberto Giacometti's famous 
work "Walking Man" appeared, because by 1947 the sculptor had finally realized and felt the vulnerability and defenselessness of man. His famous colleague, J.-P. Sartre, called these figures the embodiment of existentialism.

In addition, Giacometti introduces such a category as the interior space of the sculpture. In the work "Cage" the construction of the same name does not symbolize violence and restrictions on freedom, as traditional reasoning would suggest, but a small personal space. The dissonance was exacerbated by the size and appearance of the sculptures themselves, extremely thin and fragile when viewed in our usual environment. According to the memoirs of contemporaries, the master often carved his sculptures until they became as thin as nails, and did not shrink to the size of a pack of cigarettes. Usually, fascinated by the work, the author himself was horrified by the results when he finished the work. The inner space had to save a person from fragility.

From then on, a person, along with author, will treat consonance and coexistence with the world with irony and caution. Appeal to one's own inner worldspace, its mythologization, becomes a sign of art of the XX - XXI centuries. Such thoughts are supported by L. Vygotsky, the author of "Psychology of Art", who notes: "On the one hand, art history is increasingly in need of psychological justification. On the other hand, psychology, in order to explain behavior in general, cannot help but gravitate to the complex problems of aesthetic reaction. If we add to this the shift that both sciences are currently experiencing, the crisis of objectivism that they are covered by, this will finally determine the severity of our topic" [2, 5].

It has already been mentioned above that the presence of a metaphor is a certain criterion for classifying an art object as a work of art. It is necessary to emphasize the necessity of figurative and symbolic language, due to which the artistic transmission of aesthetic experience is possible. Metaphor correlates two dimensions - man, with his inner experiences and the surrounding reality, with his existential phenomena, as only through a symbol it is possible to contemplate transcendent meanings (semantic depths) of a certain phenomenon or object. Such knowledge reveals truths unattainable for any other form of comprehension, however, which are able to illuminate distant horizons that transcend the boundaries of a particular artistic object.

Aesthetic experience as figurative insight, in fact, turns an art object into a work of art. In addition, it involves contemplation and the ability to it, which 
is within the power of a mature viewer. After all, interactivity, which is inherent in modern art practices, involving physical or intellectual mobility, resembles the model of children's external cognition of the world around them. In today's fastpaced world, unfortunately, the value of contemplation is lost. And if the fragile post-war man began to seek salvation in his inner subjective world, his equally fragile descendant amplifies the effect of immersion in virtual reality. "Now there is a powerful experimental period in all spheres of aesthetic consciousness, in all mental and practical spheres. Man is actively moving from real life to the virtual network, and all the "arts" and other practices follow him. The future of art and aesthetic consciousness, if it is still needed by a new person, in case this person still has this future, is in the Web" $[1,228]$.

Interestingly enough, the afore-mentioned academician V. Bychkov, considering the problem of aesthetic taste, which was formed in the days of Impressionism and avant-garde (early twentieth century), noted that most of the recipients of the time did not perceive the emphasis on purely picturesque, i.e. aesthetic qualities. The artistic taste of those art connoisseurs was not worse, perhaps even superior to ours. "The main thing is that he was a little differently oriented in each certain epoch. In particular, in the past, the most important place in it was occupied by mimetic and idealizing principles of fine arts" [1, 232]. To understand most of the new avant-garde art, devoid of non-painting elements that saturated pre-impressionist painting, required some historical distance and a kind of training of taste.

It is not for nothing that optics, already as a full-fledged field of physics, had a great influence on the art of the late XIX - early XX centuries (work with color, the influence of pictorial principles and effects of photography and cinema). Mimesis and idealization are a thing of the past. Increasingly, in the early twentieth century, the artist, realizing his cultural and avant-garde mission, tries to convey not aesthetic but existential experience, using the deformation of the object, abstract compositions, or, in general, openly focused on psychoanalysis. Such a new "optics" focuses mental attention on the inner, on the very human; thus, respectively, forms a new view of the majority.

Focus on subjective experiences leads to the formation of the phenomenon of mythopoetic thinking of the author (because it concerned all arts - from poetry to architecture), which coincided with the great interest of scientists, 
philosophers and artists in myth in the second half of XIX - early XX centuries. It is this tendency that is embodied in the artistic arts of modernism and postmodernism. The famous researcher K. Levi-Strauss, whose scientific research influenced the development of art history, found that the specificity of mythological thinking lied in its relative autonomy from social infrastructures. Through a personal myth, with its original images, the author communicates with others, giving the viewer the opportunity not only to observe, but also to recognize their own revelations in this emotional unity. While the denial of any metanarratives adhered to by postmodernism was the ultimate evidence of the gap between the collective unconscious and the individual.

Thus, the art of the second half of the XX - early XXI centuries need empathy as opposed to contemplation, which, in fact, is aimed at such art practices as performance, happening, installations, for which interactivity is an important condition.

In the context of the above, the artistic search of Ukrainian authors is of special interest. It should be noted that the Ukrainian artistic tradition has always been associated with artistic processes that took place throughout Europe. However, significant archetypal features, which took place in ancient times, formed a kind of worldview, which was reflected in the artistic dimension. These specific features were not noticed even by S. Freud, as evidenced by his student and famous writer, philosopher of German-Russian origin Lou Andreas-Salome: "On the Russians (the author did not distinguish Ukrainians separately, because even being with R. Rilke in Kyiv, visiting the grave of Taras Shevchenko in Kaniv, she perceived everything as Russia - I.S.) often been said, including S. Freud, that this "material", whether pathological or healthy, combines two things that are not so often found together: the simplicity of the structure and the ability in some cases to describe even the most complex things, using all the strange richness of language, finding names for the most complex mental states. It is on this expressiveness that all Russian literature is based. Not only its great, but also less significant works" [8, 36].

Contemplation of the world, inherent in the Ukrainian mentality, and the experience of appropriate emotions create the impression of sacred omnipresence. Due to this, the early twentieth century saw the appearance of the Ukrainian avantgarde, with its sense of c cosmicality, and at the end of the twentieth century Ukrainian transavant-garde, Kyiv representatives of which called themselves the 
rearguard. The famous Kyiv artist M. Vaisberg testifies that the "Kyiv School" is strong - I mean painting and graphics. Ihor Dychenko, for example, held an exhibition of Kazimierz Malević and exhibited my and Aleksandr Tustokov's works. This shows that our art exists in one artistic field, in some paradigm, where we are the same in terms of meaning, but live in different times" [6].

According to Matviy, Kyiv artists, who called themselves the rearguard, were concerned not with a new method in art, but with solving certain worldview issues, namely, the preservation of basic values, which manifested themselves as humanistic, anthropocentric, figurative painting. The artistic rearguard was a reaction to the active spread of postmodernist practices in contemporary Ukrainian art, at the same time, its participants felt the irrelevance of their ideas. "In my opinion, if we abandon axiology, then art does not exist at all. It lies in these categories," said M. Vaisberg [6]. Art critic Andrei Mokrousov even created the manifesto.

The figurative, being part of the works by Kyiv rearguard artists, has its own ring. It comes not from the surrounding images, but from the very core of our being, from the "the world behind the looking-glass." "With every passing year, young people more consistently study the possibilities of art as the embodiment of the "landscape of the soul", says the Ukrainian researcher O. Petrov about the artists of the 1980s [5,29]. Of course, this influenced the development of a peculiar plastic language.

Taking into account the specificity of the development of modern foreign art, we may state, that the "the dominant of the Ukrainian arts is based on the category of the beauty, on the search of the plastic form, colorism, culture of composition" [ 5 , 58]. The presence of the figurative in the works of Ukrainian artists testifies to the continuation of the tradition of contemplation, when the inner experience still tries not to lose either the dialogue or the harmony with the surrounding world. Art, as a fact of figurative insight, reliably protects against the dominance of art practices, thus, guarantees art its eternal desire to know sacred truths, which cannot be done in a state of extreme subjective opposition.

\section{REFERENCES}

1. Bychkov V. V., Mankovskaya N. B. (2017) Khudozhestvennost kak metafizicheskoe osnovanie esteticheskogo opyta i kriteriy opredeleniya podlinnosti iskusstva [Artistry as a metaphysical foundation of aesthetic experience and a criterion 
Iryna Solyarska-Komarchuk. Walking man: from aesthetics to art practices

for determining the authenticity of art]. Vestnik slavyanskikh kultur. Moskva : Institut filosofii RAN. no. 1, pp. 220-241. (in Russian).

2. Vygotskiy L. S. (1998). Psikhologiya iskusstva. [Psychology of art]. Rostov na Donu : Feniks. (in Russian).

3. Levchuk L. T. (ed). (2005) Estetyka : pidruchnyk [Aesthetics: textbook]. Kyjiv : Vyshha shkola. (in Ukrainian).

4. Levi-Strosc K. (2001). Strukturnaya antropologiya [Structural Anthropology]. Moskva : EKSMO-Press. (in Russian).

5. Petrova O. (2015). Tretje Oko. Mystecjki studiji [Third Eye: Art studios] : monoghr. zb. st. Kyjiv : Feniks. (in Ukrainian).

6. Soljarsjka-Komarchuk I. O. (2021) Aktualjnistj mifopoetyky v konteksti mystectvoznavchykh doslidzhenj tvoriv suchasnogho mystectva [The relevance of mythopoetics in the context of art studies of works of modern art]. Scientific Collection "InterConf», (51): with the Proceedings of the $9^{\text {th }}$ International Scientific and Practical Conference «Scientific and Practical: Implementation to Modern Society» (April 18-19 2021). Manchester, Great Britain : Peal Press Ltd, pp. 522-530. (in Ukrainian).

7. Abdulaeva R. Matvey Vaysberg: «V tvorchestve nuzhna osobaya smes sluchaynosti i primenennykh usiliy» [Matvey Vaysberg: «Creativity needs a special mixture of randomness and applied effort»]. Available at: https://www. prostranstvo.media/matvej-vajsberh-v-tvorchestve-vazhna-osobaia-smessluchajnosty-y-prymenjonnykh-usylyj/ (accessed 16 July 2021). (in Russian).

8. Brailovskaya G. (2010) Matvey Vaysberg - gumanist i prosvetitel [Matvey Vaysberg - humanist and educator]. Kiev. Available at: http://be-inart.com/ post/view/654 (accessed 11 July 2021). (in Russian).

9. Garmash L. Lu Salome (udivitelnaya istoriya zhizni i priklyucheniy dukha $\mathrm{Lu}$ fon Salome) [Lou Salome (the amazing story of the life and adventures of the spirit of Lou von Salome]. Available at: https://www.litmir.me/ $\mathrm{br} / \mathrm{b}=103914 \& \mathrm{p}=1$ (accessed 4 July 2021). (in Russian).

10. Shagayushchiy chelovek II. [Walking Man II]. Available at: https://artchive.ru/albertogiacometti/works/382560 Shagajuschij_ chelovek_II. (accessed 12 July 2021). (in Russian).

11. Kruglikov V. Alberto Dzhakometti. Gumanizm kak ekzistentsializm [Alberto Giacometti. Humanism as existentialism]. Available at: https://adindex.ru/ publication/gallery/2012/11/12/94537.phtml (accessed 15 July 2021). (in Russian). 